\title{
IMPLEMENTASI PENGABDIAN MASYARAKAT MELALUI PELAKSANAAN DIRASAH ISLAMIYAH UNTUK MUSLIMAH DI DESA TUKAMASEA
}

\author{
Munawara \\ Sekolah Tinggi Ilmu Islam dan Bahasa Arab (STIBA) Makassar \\ munawwarah@stiba.ac.id \\ Iskandar \\ Sekolah Tinggi Ilmu Islam dan Bahasa Arab (STIBA) Makassar \\ iskandar@stiba.ac.id
}

\section{Keywords : \\ Tukamasea Village, Dirosa Islamiyah, Muslim woman, KKN STIBA.}

\begin{abstract}
The implementation of community service conducted by students of KKN STIBA Makassar aimed to facilitate the improvement of the quality of understanding of Islam for Muslim women in Tukamasea Village, Bantimurung District, Maros Regency. The implementation of community service through Dirosa Islamiyah was actualized through various Islamic education and teaching programs for Muslim women in Tukamasea Village. Through various Islamic dirosah activities for Muslim women in Tukamasea Village, it can be concluded that some Muslim women in Tukamasea Village before participating in the Islamic dirosah program have minimum knowledge and understanding of Islam and after participating in Islamic Islamic education activities in Tukamasea Village, they have increased knowledge and understanding of Islam.
\end{abstract}

\section{Kata kunci :}

Desa Tukamasea, Dirosa Islamiyah, Muslimah, KKN STIBA.

\begin{tabular}{l} 
ABSTRAK \\
\hline Implementasi pengabdian masyarakat yang dilaksanakan oleh \\
mahasiswi KKN STIBA Makassar bertujuan untuk menfasilitasi \\
peningkatan kualitas pemahaman agama Islam bagi muslimah di \\
Desa Tukamasea, Kecamatan Bantimurung, Kabupaten Maros. \\
Implementasi pengabdian masyarakat melalui dirosa islamiyah \\
diwujudkan lewat berbagai program pendidikan dan pengajaran \\
Islam untuk muslimah di Desa Tukamasea. Melalui berbagai \\
kegiatan dirosa islamiyah untuk muslimah di Desa Tukamasea dapat \\
disimpulkan bahwa sebagian muslimah di Desa Tukamasea sebelum \\
mengikuti program dirosah islamiyah memiliki pengetahuan dan \\
pemahaman keislaman yang minim dan setelah mengikuti kegiatan \\
dirosah islamiyah muslimah di Desa Tukamasea memiliki \\
peningkatan dalam hal pengetahuan dan pemahaman keislaman.
\end{tabular}




\section{PENDAHULUAN}

\section{A. Profil Desa Tukamasea}

Tukamasea adalah sebuah nama desa yang berada di wilayah Kecamatan Bantimurung, Kabupaten Maros, Provinsi Sulawesi Selatan. Desa Tukamasea terbentuk pada tahun 1959 berdasarkan UU Nomor 29 Tahun 1959. Desa Tukamasea berstatus sebagai desa defenitif dan tergolong pula sebagai desa swadaya. ${ }^{1}$ Desa Tukamasea terdiri dari 5 Dusun, yaitu dusun Pajjaiang, dusun Bontokappong, dusun Bungaeja, dusun Manarang, dan dusun Amessangeng. Desa Tukamasea memiliki batas-batas wilayah sebagai berikut:

Utara : Berbatasan dengan kabupaten Pangkep

Selatan: Berbatasan dengan desa Mangeloreng

Barat : Berbatasan dengan desa Baruga

Timur : Berbatasan dengan kelurahan Leang-Leang

Desa Tukamasea memiliki luas wilayah 20,14 km2, dengan sebagian besar wilayahnya merupakan lahan persawahan, sebagian kecil lagi merupakan dataran tinggi dan dataran rendah. Desa Tukamasea juga terdapat banyak bukit-bukit bertebing yang menjulang tinggi, yang membuat panorama keindahan alamnya semakin terlihat. Selain itu, ada pula beberapa sungai-sungai kecil yang mengalir serta sistem irigasi di beberapa tempat yang menunjang proses pengairan lahan-lahan persawahan. Oleh karena itu, mayoritas penduduk Desa Tukamasea berprofesi sebagai petani. Selebihnya ada yang berprofesi sebagai pedagang, guru, pegawai, dan pengusaha.

\section{B. Potensi Lokal Desa Tukamasea}

Penduduk Desa Tukamasea pada umumnya bermata pencaharian sebagai petani sawah dasar pertanian adalah pertanian sawah. Sumber daya alam yang dihasilkan seperti padi, jagung, kedelai dan tanaman holtikiltura lainnya. Sebagian kecil warga berdagang hasil tanaman seperti berdagang eceran. Ada dua macam petani (pemilik dan buruh). Dan sebagian masyarakat Desa Tukamasea ada juga yang bergelut dibidang pemerintahan dan berstatus PNS.

Keadaan penduduk berdasarkan mata pencaharian dapat digambarkan sebagai kehidupan sosial ekonomi dari sumber masyarakat tersebut. Mayoritas masyarakat desa Tukamasea berprofesi sebagai petani. Adapun selebihnya ada yang berprofesi sebagai guru, pegawai, pedagang dan pekerja pabrik di bosowa. Jenis tanaman yang dibudidayakan pada lahan pertanian seperti padi, jagung, kangkung, tanaman cabai, tomat dan kacang tanah. Sedangkan untuk lahan kebun selain tanaman diatas juga ditanami tanaman jangka panjang yaitu jenis tanaman jangka panjang. Dari hasil

\footnotetext{
${ }^{1}$ Profil Desa Tukamasea
} 
budidaya tanaman tersebut pada umumnya dijadikan sumber makanan pokok sekaligus sebagai mata pencaharian masyarakat yang sebagian hasilnya dijual di pasar.

Sektor peternakan juga merupakan sektor yang cukup berkembang di masyarakat. Beberapa komoditas peternakan yang dibudidayakan warga adalah ayam pedaging, ayam petelur, bebek, itik dan sapi. Pada umumnya masyarakat mengandangkan hewan ternaknya di sekitar kebun mereka bahkan ada yang di tengah sawah, sehingga memudahkan untuk memberi pakan. Desa Tukamasea dengan lahan persawahan yang cukup luas menjadikan jasa peminjaman traktor sebagai salah satu hal yang digeluti oleh masyarakat, karena petani tidak lagi menggunakan sapi untuk membajak sawah, namun sudah menggunakan jasa traktor, dan jasa ini cukup mudah untuk didapatkan karena banyak petani yang menyewakan traktor miliknya.

Sektor usaha jual beli juga berkembang dengan baik di Desa Tukamasea, utamanya jual beli kebutuhan pokok. Usaha jual beli kebutuhan pokok biasanya dilakukan di pasar baik yang ada di Desa sendiri maupun diluar Desa bahkan diluar kecamatan. Termasuk masyarakat yang membuat kios di depan rumah untuk menjual kebutuhan sehari-hari rumah tangga. Dalam aktivitasnya, masyarakat Desa Tukamasea sebagian besar menggunakan jasa transportasi angkutan umum (pete-pete) yang dimanfaatkan oleh masyarakat dalam dan luar Desa dan digunakan untuk ke pasar, antar jemput anak sekolah dan lain-lain. Adapun jasa sopir mobil truk lebih banyak dimanfaatkan untuk kebutuhan pabrik bosowa yang terletak di Desa Baruga yang bersebrangan dengan Desa Tukamasea.

\section{PEMBAHASAN}

Sekolah Tinggi Ilmu Islam dan Bahasa Arab (STIBA) Makassar merupakan institusi Perguruan Tinggi Agama Islam yang berkonsentrasi pada pengaderan dai dan ulama, yang mana salah satu misi utama dari intitusi ini adalah menyebarkan ajaran Islam berdasarkan tuntunan Alquran dan Sunnah sesuai pemahaman Al-Salafusshalih melalui gerakan dakwah yang dipelopori oleh para ahlul ilmi. Maka dalam rangka mewujudkan misi tersebut, STIBA Makassar kemudian menjabarkan misinya secara teknis dalam program-program pengabdian kepada masyarakat, diantaranya dalam bentuk Kuliah Kerja Nyata (KKN) berbasis riset.

Program KKN merupakan salah satu bentuk kegiatan perkuliahan yang dilakukan di lapangan yang berorientasi pada pembelajaran dan pemberdayaan masyarakat, program ini sebagai bentuk nyata keterlibatan institusi STIBA Makassar dalam upaya menumbuh kembangkan kesadaran religius yang menjadi cita-cita STIBA Makassar. Program KKN STIBA Makassar dilaksanakan sekali dalam setahun, tepatnya diawal semester genap yaitu pada interval waktu antara bulan januari sampai dengan bulan maret, Program KKN diikuti oleh mahasiswa yang telah memenuhi semua persyaratan 
WAHATUL MUJTAMA': Jurnal Pengabdian Masyarakat

Vol. 1, No. 2 (2020) : Hal. 174-184

Website: https://journal.stiba.ac.id

dan ditetapkan oleh Bidang Akademik STIBA Makassar yang berkoordinasi dengan Pusat Penelitian dan Pengabdian kepada Masayarakat (P3M) STIBA Makassar.

KKN (Kuliah Kerja Nyata) merupakan mata kuliah yang wajib untuk dipenuhi oleh mahasiswa/i Sekolah Tinggi Ilmu Islam dan Bahasa Arab (STIBA) Makassar dalam menyelesaikan beban studinya di perguruan tinggi. Pada tahun akademik 2019/2020 STIBA Makassar menyelenggarakan kerjasama KKN angkatan III dengan pemerintah Kecamatan Bantimurung Kabupaten Maros Provinsi Sulawesi Selatan. Desa Tukamasea adalah salah satu desa yang menjadi posko penempatan mahasiswa KKN STIBA Makassar angkatan III di wilayah Kecamatan Bantimurung.

Dalam hal keagamaan penduduk desa Tukamasea seluruhnya beragama Islam, oleh karena itu fasilitas ibadah yang tersedia di desa Tukamasea hanya fasilitas peribadatan untuk kaum muslimin, yakni mesjid sejumlah 7 buah dan Mushalla sebanyak 2 buah, serta tidak terdapat fasilitas peribadatan yang lain di desa Tukamasea. ${ }^{2}$ Berdasarkan kondisi tersebut, maka program KKN yanglaksanakan di desa Tukamasea adalah Dirosa Islamiyah yang terimplementasi dalam berbagai pelaksanaan program kerja.

\section{Peran Pendidikan Islam dalam Masyarakat}

Pendidikan adalah bagian yang tidak terpisahkan dari kehidupan manusia, termasuk di dalamnya Pendidikan Islam. ${ }^{3}$ Dalam literatur Islam, konsep pendidikan dikembangkan dari beberapa term, antara lain tarbiyah, ta'lim dan ta'dib. ${ }^{4}$ Namun Istilah yang sering dirujuk untuk merumuskan konsep pendidikan Islam adalah term "tarbiyah", sehingga penamaan aktivitas pendidikan pada jenjang pendidikan tinggu menggunakan istilah Kulliyat al-Tarbiyah, atau yang di Indonesia disebut dengan Fakultas Tarbiyah. ${ }^{5}$

Pendidikan Islam jelas mempunyai peranan penting dalam peningkatan kualitas SDM. Konferensi Internasional Pertama tentang pendidikan Islam di Mekkah tahun 1977 merumuskan tujuan pendidikan Islam sebagai berikut:" "Pendidikan bertujuan mencapai pertumbuhan kepribadian manusia yang menyeluruh secara seimbang mellaui latihan jiwa, intelek diri manusia, perasaan dan indera. Karena itu pendidikan harus mencakup pertumbuhan manusia dalam segala aspeknya: spritual, intelektual, imajinasi,

\footnotetext{
${ }^{2}$ Iskandar, I., \& Amirullah, M. (2020). Pelaksanaan Dirasah Qur'aniyah sebagai Upaya Peningkatan Kualitas Baca Al-Qur'an di Desa Tukamasea Kabupaten Maros. WAHATUL MUJTAMA': Jurnal Pengabdian Masyarakat, 1(1), 42-53. Hal 46.

${ }^{3}$ Rizka Harfiani dan Mavianti. PKM Peningkatan Kualitas Guru PAUD Dalam Pembelajaran Pendidikan Agama Islam Berbasis Pendidikan Inklusif di Kecamatan Sunggal Kabupaten Deli Serdang. IHSAN: Jurnal Pengabdian Masyarakat, Vol.1, No.1 (2019): h.85

${ }^{4}$ Hasan Langgulung, Asas-asas Pendidikan Islam, (Jakarta: Pustaka Al-Husna, 1992): h.4-5

${ }^{5}$ Ahmad Syah. Term Tarbiyah, Ta'lim, dan Ta'dib dalam Pendidikan Islam: Tinjauan dari Aspek Semantik. Al-Fikra: Jurnal Ilmiah Keislaman, Vol.7, No.1, (2017): h.140

${ }^{6}$ Azyumardi Azra. Pendidikan Islam: Tradisi dan Modernisasi di tengah Tantangan Milenium III. (Jakarta: Prenada Media, 2019): h.64
} 
WAHATUL MUJTAMA': Jurnal Pengabdian Masyarakat

Vol. 1, No. 2 (2020) : Hal. 174-184

Website: https://journal.stiba.ac.id

fisik, ilmiah, bahasa baik secara individual maupun secara kolektif, dan mendorong semua aspek ini kearah perbaikan dan mencapai kesempurnaan. Tujuan terakhir pendidikan muslim terletak pada perwujudan ketundukan hang sempurna kepada Allah baik secara pribadi, komunitas, seluruh ummat manusia. Tujuan pendidikan Islam dalam konfrensi tersebut sejalan dengan tujuan pendidikan dalam konteks keindonesiaan. Pendidikan Islam diakui sebagai bagian dari subsistem pendidikan Nasional. Hal ini dapat dilihat dari posisi agama (pendidikan agama) dalam UU Sisdiknas 2003.

Secara umum, pendidikan di Indonesia dimaksudkan dalam rangka meningkatkan kualitas pribadi dan kualitas hidup masyarakat serta bangsa. ${ }^{7}$ Hal ini sebagaimana tert uang dalam Undang-Undang No. 20 tahun 2003 tentang Sistem Pendidikan Nasional yang menyatakan bahwa "Pembangunan nasional dalam bidang pendidikan merupakan upaya mencerdaskan kehidupan bangsa dan meningkatkan kualitas manusia Indonesia dalam mewujudkan masyarakat yang maju, adil dan makmur serta memungkinkan warga negaranya mengembangkan diri, baik berkenaan dengan aspek jasmaniah maupun rohaniah berdasarkan Pancasila dan UUD 1945". Disebutkan juga dalam UU No. 20 tahun 2003, bahwa "Pendidikan nasional bertujuan mengembangkan potensi peserta didik agar manusia yang beriman dan bertaqwa terhadap Tuhan Yang Maha Esa, berakhlak mulia, sehat, berilmu, cakap, kreatif, mandiri, dan menjadi warga negara yang demokratis serta bertanggungjawab dalam rangka mencerdaskan kehidupan bangsa."

Tujuan yang hendak dicapai melalui pendidikan islam tentu memiliki kerangka yang menunjang dalam rangka pencapaian tujuan pendidikan nasional secara umum. ${ }^{9}$ Pendidikan Islam secara teknis akan berupaya untuk meningkatkan kualitas sumber daya manusia yang bermuara pada pembangunan peradaban manusia yang bermartabat. ${ }^{10}$

\section{Program Pendidikan Muslimah di Desa}

Muslimah memegang peranan penting terhadap maju tidaknya sebuah peradaban. Dari sentuhan para muslimah yang terbina dengan baik akan terlahir generasi-generasi berkualitas yang dapat menjadi penentu arah angin masa depan bangsa. Oleh karena itu Islam menempatkan perempuan pada posisi yang sangat mulia. Peran para muslimah dalam melahirkan generasi yang berkualitas sangat ditentukan oleh sejauh mana kualitas para muslimah itu sendiri. Kualitas para muslimah ini juga akan sangat ditentukan sejauh mana kualitas pendidikan dan pembinaan yang diperoleh.

7 Ari Hasan Anshori. Strategi Peningkatan Sumber Daya Manusia dalam Pendidikan Islam. JURNAL QATHRUNÂ Vol. 2 No. 2 (2015): h.20

${ }^{8}$ Undang-undang No 20 tahun 2003

9 Ahmad Furchan, Pengantar Penelitian Dalam Pendidikan, (Yogyakarta: Pustaka Belajar, 2004): h. 14 .

${ }^{10}$ Nurlaila. Model-Model Pengembangan Pendidikan Agama Islam di Sekolah/ Perguruan Tinggi. Ta’dib XVI, (2011): h.270 
WAHATUL MUJTAMA': Jurnal Pengabdian Masyarakat

Vol. 1, No. 2 (2020) : Hal. 174-184

Website: https://journal.stiba.ac.id

Program pembinaan, pendidikan, dan pemberdayaan bagi masyarakat dapat diselenggarakan secara formal, non formal, dan informal. ${ }^{11}$ Pada penelitian ini fokus diselenggarakan secara informal dan dikhususkan untuk muslimah yang ada di Desa Tukamasea.

\section{Gambaran Pelaksanaan Dirosa Islamiyah untuk Muslimah di Desa Tukamasea}

\section{Tarbiyah Islamiyah}

Langkah awal yang dilakukan adalah mencari data yang ikut tarbiyah dari pihak Muslimah Wahdah Cabang di desa Tukamasea kemudian mencari halaqah yang diberikan lalu menetapkan seorang anggota KKN untuk membina atau mengisi tarbiyah di halaqah tersebut.

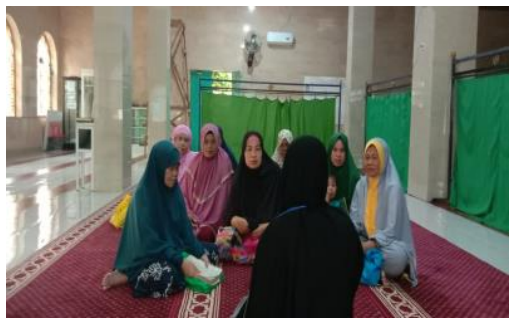

\section{Gambar 1. Pelaksanaan Tarbiyah Islamiyah}

\section{Taklim Muslimah}

Mengatur jadwal rutin pekanan dengan petugas majelis ta'lim, kemudian melakukan sosialisasi kepada seluruh anggota secara langsung ataupun dengan media sosial. Lalu menentukan jadwal anggota KKN untuk menyampaikan materi ta'lim dengan bahasa yang mudah dipahami oleh masyarakat. Suasana ta'lim yang selalu ramai dengan candaan ibu-ibu dalam mendengarkan dan membenarkan isi ta'lim yang sesui dengan realita. Faktor pendukung adalah antusias sebagian ibu-ibu yang tinggi. Adapaun tantangannya adalah Ibu-ibu pada umumnya lebih tertarik untuk belajar mengaji daripada ta'lim.

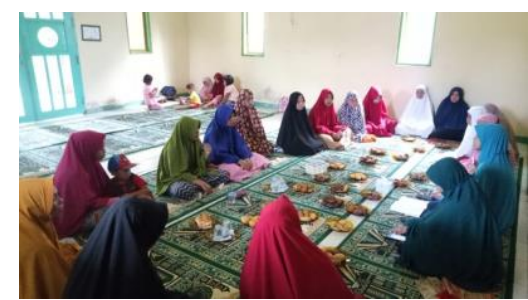

Gambar 2. Pelaksanaan Taklim Muslimah

\footnotetext{
${ }^{11}$ Sujian Suretno, Aceng Zakaria, Ayub Pardian, Iwan Ginawan. (2020). Implementasi Pendidikan Masyarakat Berbasis Masjid di Islamic Center Palm Raya Melalui Kegiatan Pengabdian Kepada Masyarakat di Kelurahan Bubulak, Kecamatan Bogor Barat, Kota Bogor. Khidmatul Ummah: Jurnal Pengabdian Kepada Masyarakat, 1(01), 66-83. Hal. 68
} 
WAHATUL MUJTAMA': Jurnal Pengabdian Masyarakat

Vol. 1, No. 2 (2020) : Hal. 174-184

Website: https://journal.stiba.ac.id

\section{Mengajar Dirosa}

Langkah awal yang dilakukan adalah dengan mendata masyarakat yang ingin ikut pembelajaran Dirosa kemudian membagi tugas kepada anggota KKN untuk melanjutkan pembinaan pada kelompok belajar yang telah terbentuk. Sebagian peserta masih sangat kesulitan dalam menyebutkan huruf-huruf sesuai dengan kiadah bacaannya, bahkan masih ada yang buta huruf. Solusinya pengajar secara bertahap mengajarkan tentang cara penyebutan huruf-huruf dan selalu memberi semangat kepada peserta.

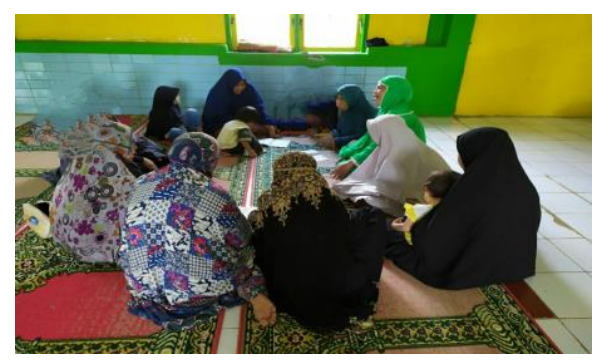

\section{Gambar 3. Pelaksanaan Dirosa Islamiyah}

\section{Tahsinul Qiro'ah}

Langkah awal yang dilakukan adalah mendata masyarakat (terutama para remaja) yang ingin mengikuti pembelajaran tahsin kemudian melanjutkan pembinaan pada kelompok belajar yang telah terbentuk. Banyak masyarakat yang berusia lanjut yang ingin mengikuti kegiatan tahsinul qiro'ah, serta ikut berpartisipasi langsung dalam praktek membaca Al-Qur'an sesuai kaidah tajwid. Sangat terlihat antusiasme dan semangat yang tinggi dari ibu-ibu dan remaja dalam mengikuti tahsin. Adapun kendala yang dihadapi adalah banyaknya kesibukan para remaja yang ingin mengikuti tahsin hingga membuat beberapa jadwal tahsin sulit untuk ditentukan dan tidak terlaksana dengan maksimal. Solusinya anggota KKN mencari waktu khusus atau memilih hari libur sebagai jadwal tetap

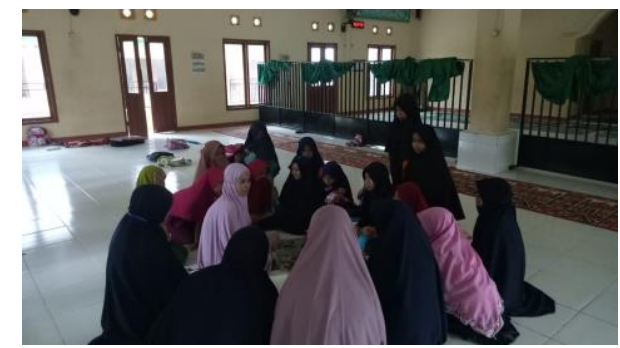

\section{Gambar 4. Pelaksanaan Tahsinul Qiro'ah}

\section{Ta'lim Fikih}

Langkah awal yang dilakukan adalah mengatur jadwal rutin pekanan, kemudian melakukan sosialisasi kepada masyarakat dengan langsung ataupun dengan media sosial. Lalu menyepakati anggota KKN untuk menyampaikan materi ta'lim dengan bahasa 
yang mudah dipahami masyarakat. Apalagi kebanyakan pesertanya adalah mereka yang telah berusia lanjut. Faktor pendukung dalam kegiatan ini adalah semangat dan antusias yang tinggi dari masyarakat serta masjid yang bersih dan ber-AC membuat kondisi ta'lim fikih menjadi nyaman. Terkadang hujan yang sangat deras membuat kegiatan pernah tidak terlaksana.

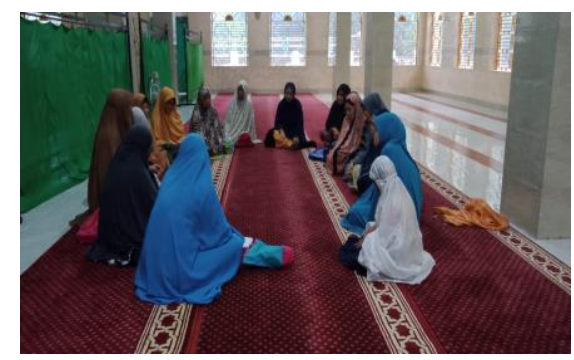

\section{Gambar 5. Pelaksanaan Taklim Fiqih}

\section{Mengajar PAI di sekolah dan madrasah}

Setiap anggota diberikan jadwal yang sudah disepakati dalam musyawarah. Kemudian melakukan pengajaran sesuai dengan kurikulum yang berlaku pada sekolah/madrasah yang bersangkutan. Siswa dan siswi yang semangat dan antusias dalam mengikuti pelajaran. Kepala sekolah dan guru yang terbuka serta ramah terhadap mahasiswi KKN. Meskipun terdapat sebagian siswa yang cuek dan tidak memperhatikan materi yang diterangkan. Solusinya mahasiswa KKN melakukan Ice Breaking untuk mengembalikan semangat dan konsentrasi para siswa.

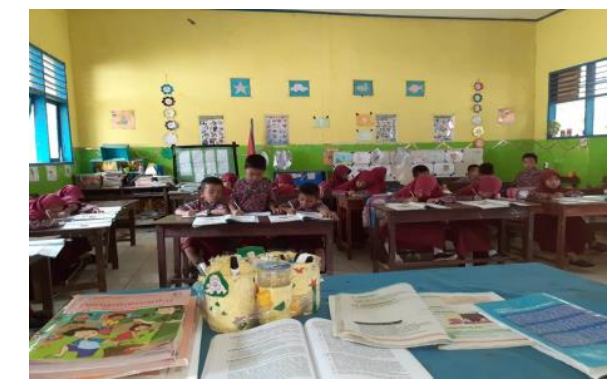

\section{Gambar 6. Pengajaran PAI di Sekolah}

\section{Mengajar TK/TPA}

Langkah yang dilakukan diawal adalah mendata TK/TPA yang ada di desa Tukamasea lalu membagi tugas kepada anggota KKN untuk mengajar sesuai dengan tempat yang telah disepakati di dusun mana mereka membina anak-anak TK/TPA. Beberapa santri dan santriwati sangat antusias menunggu kedatangan mahasiswa KKN yang akan mengajar mereka. Faktor pendukung adalah lokasi TPA yang bersih serta semangat dan antusias santri yang tinggi. Sedangkan faktor yang menjadi kendala adalah Waktu mengajar terkadang bertepatan dengan jadwal yang lain dan santri terkadang bosan dengan sistem pengajaran yang biasa-biasa saja. Solusinya mahasiswa KKN lebih 
WAHATUL MUJTAMA': Jurnal Pengabdian Masyarakat

Vol. 1, No. 2 (2020) : Hal. 174-184

Website: https://journal.stiba.ac.id

mengatur waktunya dengan baik dan memberikan semacam permainan agar anak-anak santri kembali semangat dan fokus belajar.

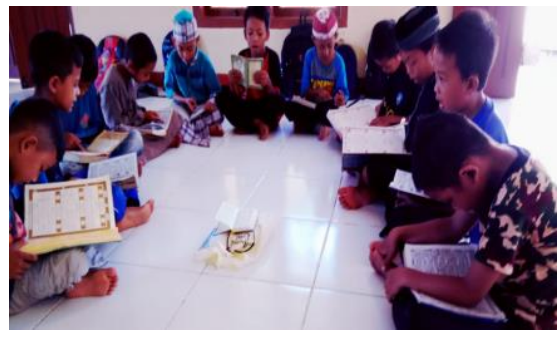

\section{Gambar 7. Pengajaran TKA/TPA}

\section{Ta'lim Remaja}

Langkah awal yang dilakukan adalah mengatur jadwal rutin pekanan pada sekolah yang telah ditentukan, kemudian melakukan sosialisasi kepada siswi atau santri secara langsung ataupun dengan media sosial. Lalu menentukan jadwal anggota KKN untuk menyampaikan materi ta'lim dengan bahasa yang mudah dipahami masyarakat. Semangat dan antusias yang tinggi dari para pelajar menjadi faktor yang sangat mendukung dalam pelaksanaan kegiatan ini. Adapun kendala yang dihadapi adalah Waktu pelaksanaan yang bersamaan dengan jam pulang para siswi sehingga beberapa dari mereka lebih memilih untuk pulang.

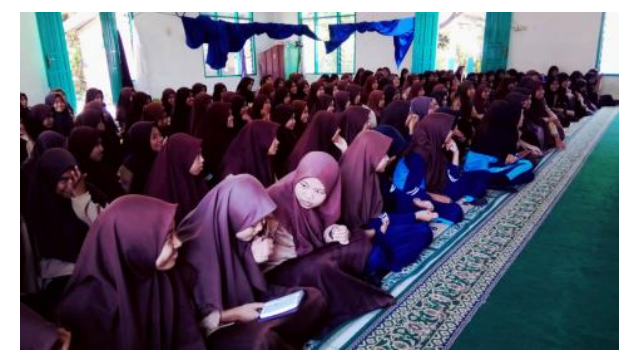

\section{Gambar 1. Pelaksanaan Taklim Remaja}

\section{Ta'lim Lughoh (Pembelajaran Bahasa Arab)}

Langkah awal yang dilakukan adalah mencari peserta dari kalangan remaja kemudian melakukan sosialisasi lalu melaksanakan program. Pengalaman menarik dari Mengajar bahasa Arab sambil mengajar makharijul huruf. Faktor pendukung pada kegiatan ini adalah Antusias dan semangat remaja dalam mempelajari bahasa Arab. Adapun kendalanya adalah sebagian peserta masih kesulitan membaca bahasa Arab. Solusinya mahasiswa KKN menggunakan metode pengajaran yang mudah dan menarik. 


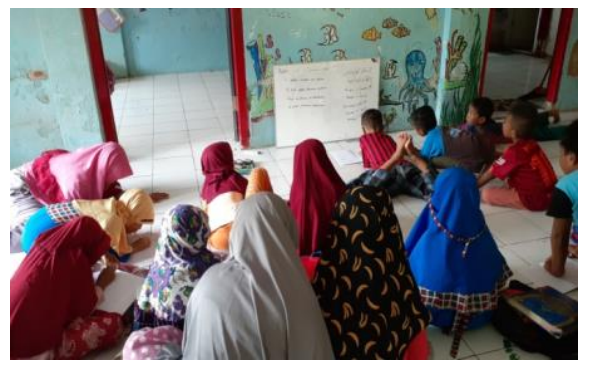

\section{Gambar 9. Pelaksanaan Taklim Lughoh}

\section{Tabligh Akbar}

Langkah awal yang dilakukan adalah membuat konsep kegiatan kemudian menyelesaikan administrasi kegiatan dan sosialisasi kegiatan lalu melaksanakan program. Dalam pelaksanaan tabligh akbar, antusias masyarakat yang turut hadir dalam kegiatan, terutama dari kalangan ibu-ibu. Faktor pendukung Perizinan dari pengurus masjid sangat mudah serta materi yang menarik yang dibawakan oleh pemateri. Faktor penghambat adalah mobilisasi masyarakat yang kurang maksimal untuk bisa hadir tepat waktu sehingga pelaksanaan kegiatan.

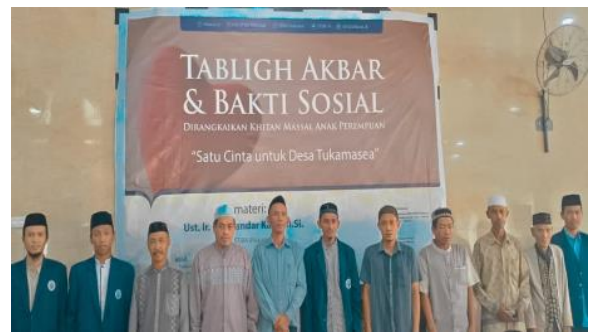

\section{Gambar 10. Pelaksanaan Tabligh Akbar}

\section{KESIMPULAN}

Pengabdian Kepada Masyarakat (PKM) dalam bentuk program kerja dirosah Islamiyah untuk muslimah di Desa Tukamasea bertujuan untuk menfasilitasi pengembangan kualitas pemahaman agama Islam muslimah di Desa Tukamasea, Kecamatan Bantimurung, Kabupaten Maros. Pengabdian masyarakat ini diharapkan berkontribusi terhadap peningkatan kualitas pengetahuan dan pemahaman keislaman muslimah secara baik dan benar. melalui Implementasi pengabdian masyarakat dengan pelaksanaan dirosa islamiyah untuk muslimah di Desa Tukamasea, disimpulkan bahwa sebagian muslimah di Desa Tukamasea sebelum mengikuti program dirosah islamiyah memiliki pengetahuan dan pemahaman keislaman yang minim dan setelah mengikuti kegiatan dirosah islamiyah muslimah di Desa Tukamasea memiliki peningkatan dalam hal pengetahuan dan pemahaman keislaman. 
WAHATUL MUJTAMA': Jurnal Pengabdian Masyarakat

Vol. 1, No. 2 (2020) : Hal. 174-184

Website: https://journal.stiba.ac.id

\section{DAFTAR PUSTAKA}

Anshori, A.H. (2015). Strategi Peningkatan Sumber Daya Manusia dalam Pendidikan Islam. JURNAL QATHRUNÂ Vol. 2 No. 2

Azra, A. (2019). Pendidikan Islam: Tradisi dan Modernisasi di tengah Tantangan Milenium III. Jakarta: Prenada Media

Furchan, A. (2004). Pengantar Penelitian Dalam Pendidikan. Yogyakarta: Pustaka Belajar

Harfiani, R., Mavianti. (2019). PKM Peningkatan Kualitas Guru PAUD Dalam Pembelajaran Pendidikan Agama Islam Berbasis Pendidikan Inklusif di Kecamatan Sunggal Kabupaten Deli Serdang. IHSAN: Jurnal Pengabdian Masyarakat, Vol.1, No.1

Iskandar, I., \& Amirullah, M. (2020). Pelaksanaan Dirasah Qur'aniyah sebagai Upaya Peningkatan Kualitas Baca Al-Qur'an di Desa Tukamasea Kabupaten Maros. WAHATUL MUJTAMA': Jurnal Pengabdian Masyarakat, 1(1), 42-53. Hal 46.

Langgulung, H. (1992). Asas-asas Pendidikan Islam. Jakarta: Pustaka Al-Husna

Nurlaila. (2011). Model-Model Pengembangan Pendidikan Agama Islam di Sekolah/ Perguruan Tinggi. Ta'dib XVI.

Syah, A. (2017). Term Tarbiyah, Ta'lim, dan Ta'dib dalam Pendidikan Islam: Tinjauan dari Aspek Semantik. Al-Fikra: Jurnal Ilmiah Keislaman, Vol.7, No.1.

Suretno, S., Zakaria, A., Pardian, A., \& Ginawan, I. (2020). Implementasi Pendidikan Masyarakat Berbasis Masjid di Islamic Center Palm Raya Melalui Kegiatan Pengabdian Kepada Masyarakat di Kelurahan Bubulak, Kecamatan Bogor Barat, Kota Bogor. Khidmatul Ummah: Jurnal Pengabdian Kepada Masyarakat, 1(01), 6683.

Undang-undang No 20 tahun 2003 